has also been associated with corticosteroid treatment, the femoral head being the site usually affected. This complication of steroid treatment may occur even when the drugs are given for conditions in which vasculitis does not occur-for example, to prevent rejection of renal allografts. ${ }^{2}$

Ihde and De Vita were the first to report the association of combination chemotherapy containing corticosteroids with the development of osteonecrosis in patients with malignant lymphoma. ${ }^{1}$ Thorne et al found those affected to be most commonly men, with Hodgkin's disease the most common underlying lymphoma and the femoral head the usual site of the osteonecrosis. ${ }^{3}$ The total dose of steroids varied from $1.4 \mathrm{~g}$ to $18.95 \mathrm{~g}$. Timothy et al showed that radiological changes preceded symptoms by six to 21 months. ${ }^{4}$

There are only two previous reports of avascular necrosis occurring with cancer chemotherapy that did not include corticosteroids. Ihde and De Vita mentioned in discussion a 15 year old boy with Burkitt's lymphoma who received cyclophosphamide alone and developed necrosis of the tibial tubercle, ${ }^{1}$ and Obrist $e t$ al reported on a patient with necrosis in the head of the humerus after treatment with cyclophosphamide, methotrexate, and fluorouracil for breast carcinoma. ${ }^{5}$

In our patient the initial signs were of bilateral knee effusions associated with periostitis. Though these might have been a manifestation of hypertrophic pulmonary osteoarthropathy, there were no lung lesions at this time and no finger clubbing. $\mathrm{He}$ subsequently developed symptoms and signs of osteonecrosis in the left femoral head, both medial femoral condyles, and the left scaphoid. Bleomycin and vinblastine are the most likely causes of the osteonecrosis because of the chronology of events. This case shows that avascular necrosis can be caused by cancer chemotherapy that does not include steroids.

\section{References}

${ }^{1}$ Ihde DC, De Vita VT. Osteonecrosis of the femoral head in patients with lymphoma treated with intermittent combination chemotherapy. Cancer $1975 ; 36: 1585-8$.

${ }^{2}$ Harrington KD, Murray WR, Kountz SI, Belzer FA. Avascular necrosis of bone after renal transplantation. F Bone foint Surg 1971;53A :203-15.

3 Thorne JC, Evans WK, Alison RE, Fournasier V. Avascular necrosis of bone complicating treatment of malignant lymphoma. Am $\mathcal{F}$ Med $1981 ; 71: 751-8$

4 Timothy AR, Park WM, Cannell LB. Osteonecrosis in Hodgkin's disease. Br F Radiol 1978;51:328-32.

5 Obrist P, Hartmann D, Obrecht JP. Osteonecrosis after chemotherapy. Lancet 1978;i:1316.

(Accepted 9 November 1983)

\title{
Erythrocyte choline concentrations and cluster headache
}

\author{
J DE BELLEROCHE, G E COOK, I DAS, R JOSEPH, I TRESIDDER, S ROUSE, R PETTY, \\ F CLIFFORD ROSE
}

\begin{abstract}
Erythrocyte choline concentrations were measured in patients with cluster headache and age related control subjects. Concentrations were significantly reduced in the patients with headache both during a cluster period and between clusters, being $58 \%$ and $55 \%$ of the control value, respectively. After two weeks' treatment with lithium, choline concentrations in the patients with cluster headache increased to 78 times the control value (mean 369.2 $\mu \mathrm{mol} / 1$ (3840 $\mu \mathrm{g} / 100 \mathrm{ml})$ compared with $4.7 \mu \mathrm{mol} / 1$ (49 $\mu \mathrm{g} / 100 \mathrm{ml}))$.

The presence of depressed erythrocyte choline concentrations during and between cluster attacks indicates that this may be a predisposing condition which results in a cluster attack only when associated with a trigger factor.
\end{abstract}

\section{Introduction}

For 10 years lithium has been known to be beneficial in cluster headache, ${ }^{1}$ patients with both episodic and chronic forms showing a high degree of improvement. ${ }^{2-4}$ The aetiology of cluster headache and the way in which lithium produces its effect are, however, unknown. Some insight into the mode of action of lithium has emerged from studies on manic depressive patients, where it has been found that administration of lithium greatly increases erythrocyte choline concentrations. ${ }^{56}$ The major part of this effect may be accounted for by the inhibitory action of lithium on choline transport that occurs in human erythrocytes, preventing outward transport of choline. ${ }^{78}$ In addition, choline concentrations in patients not receiving lithium are significantly different from those of controls in depression, Gilles de la Tourette's syndrome, and dementia. ${ }^{6-12}$ In view of these observations we have measured choline concentrations in erythrocytes and plasma of patients with cluster headache (a readily definable and homogeneous population) and compared them with those in age matched controls to establish whether abnormal choline concentrations also occur in this condition.

\section{Subjects and methods}

Patients with cluster headache were divided into three groupsthose who were between cluster periods (quiescent group), those who were experiencing a cluster period but were not receiving lithium (acute group), and those who were receiving lithium (lithium group). Patients studied satisfied the following criteria: they suffered severe unilateral head or facial pain occurring in bouts lasting 30 minutes to two hours and associated with ipsilateral lacrimation and rhinorrhoea and recurring once or more daily for weeks or months. Clusters were separated by intervals of complete freedom from pain for at least three months. Patients suffering from chronic cluster headache or 
atypical variants of the condition-for example, cluster migraine and cluster vertigo-were excluded. Patients not receiving lithium had previously been treated with ergotamine-caffeine preparations, propranolol, pizotifen, or clonidine. Lithium treatment was with slow release lithium carbonate (Priadel) $800-1600 \mathrm{mg}$ as a single daily dose. Control subjects were members of staff at Charing Cross Hospital.

Choline was analysed in extracts of erythrocytes and plasma from fasted patients and control subjects by a chemoluminescence assay ${ }^{13}$ using an internal standardisation method developed in this laboratory (de Belleroche et al, paper in preparation). After an overnight fast blood was drawn by venepuncture from patients and control subjects into tubes containing sodium heparin. Erythrocytes were sedimented at $1400 \mathrm{~g}$ for 30 minutes at $4^{\circ} \mathrm{C}$. Plasma and erythrocyte samples were deproteinised with trichloroacetic acid $(3.8 \%)$, centrifuged, and the supernatants extracted three times with three volumes of diethyl ether. Aqueous extracts were stored at $-20^{\circ} \mathrm{C}$. Choline was determined in aliquots of these extracts by enzyme induced chemoluminescence of luminol, utilising choline oxidase and horseradish peroxidase (Boehringer-Mannheim) for the reaction. Chemoluminescence produced by the oxidation of luminol was detected by an LKB 1250 luminometer.

The assay (de Belleroche et al, paper in preparation) has proved to be reliable, specific, and of high sensitivity ( $2 \mathrm{pmol})$. After an overnight fast serum cholesterol concentrations were measured by an automated cholesterol oxidase method (CHOD-PAP; BoehringerMannheim) and serum T4 and thyroid stimulating hormone concentrations by radioimmunoassay (Amersham International).

\section{Results}

Erythrocyte choline concentrations were significantly depressed in the patients with cluster headache, being $58 \%$ and $55 \%$ of the control value in patients in acute and quiescent phases, respectively (table I). There was little overlap in the spread of individual values between the controls and patients with headache (figure). Patients receiving lithium showed a converse effect-namely, a massive increase in erythrocyte choline concentrations up to several hundred times the untreated value. The concentration increased linearly with the amount of lithium

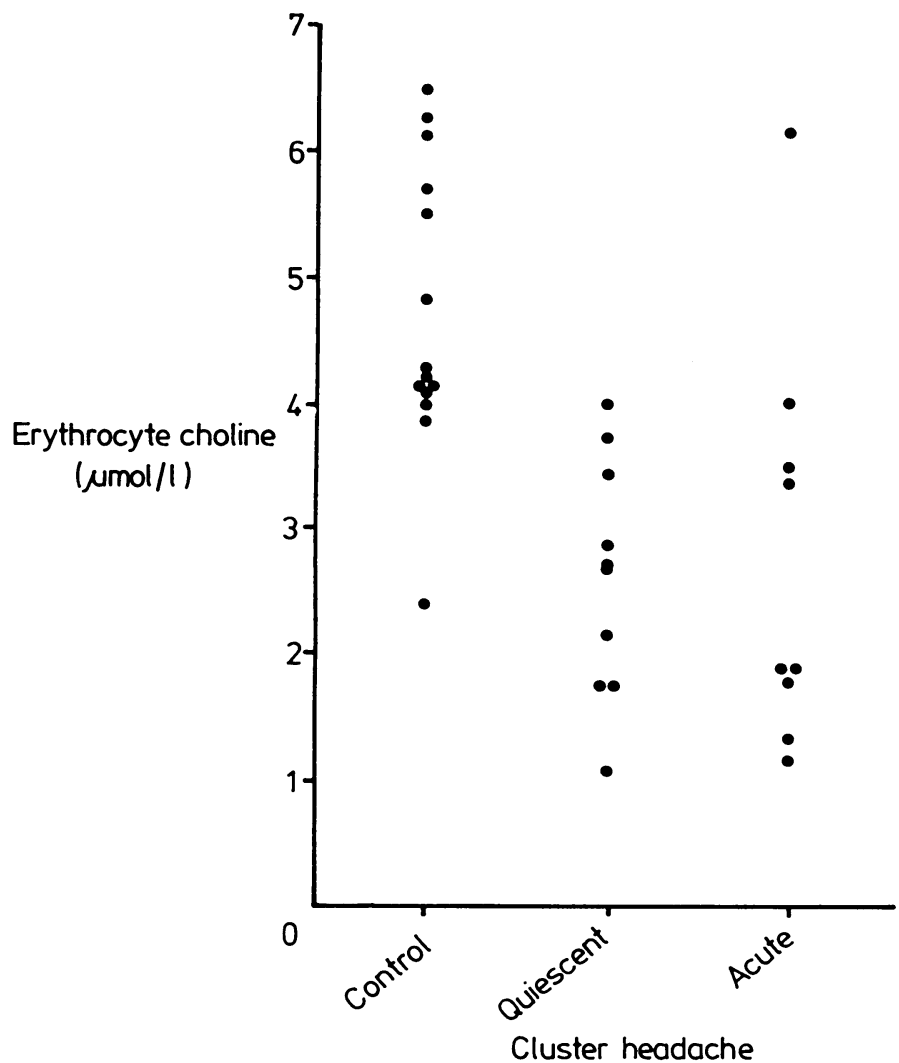

Individual cluster headache erythrocyte choline concentrations in patients with controls.

Conversion: SI to traditional units-Choline: $1 \mu \mathrm{mol} / 1 \approx 10.4 \mu \mathrm{g} / 100 \mathrm{ml}$. ingested (up to $39 \mathrm{~g}$ ). After ingesting a mean of $11 \cdot 1 \mathrm{~g}$ lithium carbonate over two weeks these patients showed a mean erythrocyte choline concentration of $369 \cdot 2(\mathrm{SEM} 50 \cdot 2) \mu \mathrm{mol} / 1(3840($ SEM 522$) \mu \mathrm{g} / 100 \mathrm{ml})$ which was 78 times the control value (table I).

TABLE I-Erythrocyte choline concentrations in patients with cluster headache and control subjects. Values are means (SEM in parentheses)

\begin{tabular}{|c|c|c|c|c|}
\hline & $\underset{\text { (years) }}{\text { Age }}$ & $\begin{array}{l}\text { No of } \\
\text { subjects }\end{array}$ & $\begin{array}{c}\text { Erythrocyte } \\
\text { choline } \\
(\mu \mathrm{mol} / 1)\end{array}$ & $\begin{array}{c}\mathrm{p} \text { Value } \\
(t \text { test })\end{array}$ \\
\hline Control subjects & $40 \cdot 4(2 \cdot 4)$ & 14 & $4.73(0.31)$ & \\
\hline $\begin{array}{l}\text { Patients with cluster headache: } \\
\text { Quiescent group } \\
\text { Acute group (no lithium) }\end{array}$ & $\begin{array}{l}47 \cdot 3(2 \cdot 8) \\
38 \cdot 8(2 \cdot 6)\end{array}$ & $\begin{array}{r}10 \\
9\end{array}$ & $\begin{array}{l}2.61(0.30) \\
2.77(0.54)\end{array}$ & $\begin{array}{l}<0.001^{*} \\
<0.01^{*}\end{array}$ \\
\hline $\begin{array}{l}\text { Lithium group treatment for two } \\
\text { weeks; (mean total dose } \\
\text { ingested } 11 \cdot 1 \mathrm{~g} \text {, range } \\
9 \cdot 6-12 \cdot 8 \mathrm{~g} \text { ) }\end{array}$ & $35.9(1.8)$ & 8 & $369 \cdot 21(50 \cdot 2)$ & $<0.001 \dagger$ \\
\hline
\end{tabular}

* Significance of difference from control concentration.

Significance of difference from control concentration and concentration in patients

Conversion: SI to traditional umits - Choline: $1 \mu \mathrm{mol} / \mathrm{l} \approx 10.4 \mu \mathrm{g} / 100 \mathrm{ml}$

Plasma choline concentrations, which were roughly $30-40 \%$ of those in the erythrocyte samples (control group), did not vary significantly among patients with cluster headache (all groups). Fasting cholesterol values were also measured and found to be significantly above control values in patients in the acute and quiescent groups (by $20 \%$ and $23 \%$ respectively) but not significantly different from the control value in the patients given lithium (table II). After withdrawal of treatment choline concentrations declined to normal over three to four months, a result consistent with an irreversible action of lithium on erythrocytes, and so lasting the lifetime of the cell. (Erythrocyte choline concentrations in this period - that is, within four months of lithium ingestionare omitted from table I and the figure.)

TABLE II-Serum cholesterol concentrations in patients with cluster headache and control subjects. Values are means (SEM in parentheses)

\begin{tabular}{|c|c|c|c|c|}
\hline & $\begin{array}{c}\text { Age } \\
\text { (years) }\end{array}$ & $\begin{array}{c}\text { No of } \\
\text { subjects }\end{array}$ & $\begin{array}{c}\text { Serum } \\
\text { cholesterol } \\
(\mathrm{mmol} / \mathrm{l})\end{array}$ & $\begin{array}{l}\text { p Value } \\
(t \text { test })\end{array}$ \\
\hline $\begin{array}{l}\text { Control subjects } \\
\text { Patients with cluster headache: }\end{array}$ & $38 \cdot 6(2 \cdot 8)$ & 15 & $4.97(0.21)$ & \\
\hline $\begin{array}{l}\text { Quiescent group } \\
\text { Acute group (no lithium) }\end{array}$ & $\begin{array}{l}41 \cdot 9(2 \cdot 1) \\
41 \cdot 4(2 \cdot 6)\end{array}$ & $\begin{array}{r}15 \\
8\end{array}$ & $\begin{array}{l}6.13(0.31) \\
5.96(0.43)\end{array}$ & $\begin{array}{l}<0.01^{*} \\
<0.05^{*}\end{array}$ \\
\hline $\begin{array}{l}\text { Lithium group treatment for } \\
\text { two to four weeks) }\end{array}$ & $41 \cdot 0(2 \cdot 2)$ & 9 & $5 \cdot 30(0 \cdot 25)$ & NS \\
\hline
\end{tabular}

\section{Discussion}

This study disclosed a pronounced difference from normal in the erythrocyte concentrations of choline in patients with cluster headache, both during and between attacks. We do not know whether this change is implicated in the aetiology of cluster headache or arises as a secondary phenomenon but it suggests that there may be a predisposing state which results in a cluster attack only when associated with a trigger factor. Since raised serum cholesterol concentrations were also found in both these groups hypercholesterolaemia may also be a predisposing factor.

Possible mechanisms whereby a choline deficiency might arise in cluster headache may be consequent on its role as a precursor of acetylcholine and phospholipids; and it may be relevant that changes in activity of the autonomic nervous system may give rise to some of the symptoms seen in cluster headache-for example, lacrimation and rhinorrhoea. Alternatively, the turnover of phospholipids, or specifically phosphatidylcholine, may be impaired in cluster headache, and this might have a major effect on membrane properties. Both low phospholipid concentrations and high cholesterol values would reduce membrane fluidity. 
In erythrocytes treated with lithium the choline transport system is inhibited bidirectionally, and hence choline derived from phosphatidylcholine catabolism within the cell would increase. Phospholipase D activity in human erythrocytes has been indicated from nuclear magnetic resonance studies, ${ }^{14}$ and the activity of this enzyme would be responsible for the raised choline concentrations.

The raised cholesterol concentrations are consistent with other reports of hyperlipoproteinaemia ${ }^{15}$ in cluster headache and may be contributory to the higher incidence of coronary heart disease seen in these patients. ${ }^{16}$ Abnormal thyroid function was unlikely to be the cause of the raised cholesterol concentrations since there was no noticeable increase in T4 or thyroid stimulating hormone in non-lithium treated patients. The raised circulating thyroid stimulating hormone concentrations found in some patients receiving lithium is in keeping with the benign thyroid enlargement that occurs occasionally during this treatment.

Although our work has yielded significant results which may provide a marker in cluster headache and also give some insight into the cause of the disorder, several important questions remain. Firstly, it would be of great interest to determine whether abnormal concentrations of choline are found in migraine, which is clearly distinguishable from cluster headache by the attack profile and response to treatment. Lithium is not helpful in migraine and may even exacerbate the condition, ${ }^{17}$ so that it would be useful to study whether differences in patients with migraine are reflected in erythrocyte choline values. Secondly, it would be important to examine erythrocyte concentrations of choline in patients with chronic cluster headache and the small proportion of patients with cluster headache who do not respond to lithium to determine whether the correlation extends to these conditions.

We are grateful to the Camilla Samuel Fund and the British Migraine Association for financial support, and to the laboratory staff of the chemical pathology department.

\section{References}

${ }^{1}$ Ekbom KA. Litium vid kroniska symptom av cluster headache. Opusc Med Bd 1974;19:148-56.

${ }^{2}$ Kudrow L. Lithium prophylaxis for chronic cluster headache. Headache $1977 ; 17: 15-8$

${ }^{3}$ Mathew K. Clinical subtypes of cluster headache and response to lithium therapy. Headache 1978;18:26-30.

${ }^{4}$ Lieb J, Zeff A. Lithium treatment of chronic cluster headache. $\mathrm{Br} \mathcal{F}$ Psychiatry 1978; 133:556-8.

${ }^{5}$ Jope RS, Jenden DJ, Ehrlich B, Diamond JM. Choline accumulates in erythrocytes during lithium therapy. $N$ Engl f Med 1978;299:833-4.

${ }^{6}$ Hanin I, Spiker DG, Mallinger AG, et al. Bload choline and its meaning in psychiatric and neurologic disease states. In: Pepeu G, Ladinsky H, eds. Cholinergic mechanisms. New York: 1981 :901-19.

${ }^{7}$ Martin K. Concentrative accumulation of choline by human erythrocytes. f Gen Physiol 1968;51:497-516.

${ }^{8}$ Lee G, Lingsch C, Lyle PT, Martin K. Lithium treatment strongly inhibits choline transport in human erythrocytes. Eur $\mathcal{f}$ Clin Pharmacol 1974;1:365-70.

${ }^{9}$ Hanin I, Kopp U, Spiker DG, Neil JF, Shaw DH, Kupfer DJ. RBC and plasma choline levels in control and depressed individuals: a critical evaluation. Psychiatry Research 1980;3:345-55.

${ }^{10}$ Jope RS, Jenden DJ, Ehrlich BE, Diamond JE, Gosenfeld LF. Erythrocyte choline concentrations are elevated in manic patients. Proc Natl Acad Sci USA 1980;77:6144-6.

${ }^{11}$ Comings DE, Gursey BT, Avelino E, Kopp U, Hanin I. Red blood cell choline in Tourette syndrome. In: Friedhoff AJ, Chase TN, eds. Gilles de la Tourette syndrome. New York: Raven Press, 1982:225-8.

${ }^{12}$ Barclay LL, Blass JP, Kopp U, Hanin I. Red cell/plasma choline ratio in dementia. N Engl f Med 1982;307:501.

13 Israel M, Lesbats B. Detection continue de la libelation d'acetylcholine de l'organe electrique de la chemiluminescence. C R Acad Sci [D (Paris) $1980 ; 291: 713-6$.

${ }^{14}$ Chapman BE, Beilharz GR, York MJ, Kuchel PW. Endogenous phospholipase and choline release: a study using ${ }^{1} \mathrm{H}$ NMR spectroscopy. Biochem Biophys Res Commun 1982;105:1280-7.

${ }^{15}$ Olesen J. Cluster headache associated with primary hyperlipidemia. Acta Neurol Scand 1977;56:461-4.

${ }^{16}$ Kudrow L. Prevalence of migraine, peptic ulcer, coronary heart disease and hypertension in cluster headache. Headache 1976;16:66-9.

17 Peatfield RC, Clifford Rose F. Exacerbation of migraine by treatment with lithium. Headache $1981 ; 21: 140-2$.

(Accepted 21 November 1983)

\title{
Multiplication of hepatitis $B$ virus in fulminant hepatitis $B$
}

\author{
C BRECHOT, J BERNUAU, V THIERS, F DUBOIS, A GOUDEAU, B RUEFF, P TIOLLAIS, \\ J-P BENHAMOU
}

\begin{abstract}
The presence in serum of hepatitis $B$ e antigen (HBeAg) and hepatitis $B$ virus DNA, which are each regarded as reflecting multiplication of hepatitis $B$ virus, were looked
\end{abstract}

\footnotetext{
Unité de Recombinaison et Expression Génétique (INSERM), Institut Pasteur, 75724 Paris Cédex 15, France

C BRECHOT, MD

$\checkmark$ THIERS, MD

P TIOLLAIS, MD

Unité de Recherches de Physiopathologie Hépatique (INSERM), Hôpital Beaujon, Clichy

J BERNUAU, MD

B RUEFF, $M D$

J-P BENHAMOU, MD

Laboratoire de Virologie, Hôpital Bretonneau, Tours

F DUBOIS, MD

A GOUDEAU, MD

Correspondence to: Dr C Bréchot.
}

for one to five days after the onset of hepatic encephalopathy in 64 patients with fulminant hepatitis $\mathrm{B}$. $\mathrm{HBeAg}$ and hepatitis $B$ virus DNA were found in the serum of only $24(37 \%)$ and six (9\%) patients, respectively. Hepatitis $B$ virus DNA was absent from the serum in all 13 patients positive for anti-HBs.

These findings indicate that replication of hepatitis $B$ virus stopped after the onset of hepatic encephalopathy in most of the patients and support the view that an enhanced immune response stops the replication. Agents that inhibit viral multiplication would probably not have any effect at this stage of the disease.

\section{Introduction}

Fulminant hepatitis B is an uncommon but severe complication of acute infection with hepatitis B virus. Mortality among adults with fulminant hepatitis $\mathrm{B}$ is $82 \%{ }^{1}$ and has not been appreciably reduced by any of the numerous drugs and procedures that have been proposed for treatment of the disease. ${ }^{23}$ Agents 